Proc. Estonian Acad. Sci. Geol., 2000, 49, 2, 147-156

\title{
REVISION OF THE SILURIAN BRACHIOPOD PENTAMERUS SAMOJEDICUS KEYSERLING, 1846 FROM THE TIMAN RIDGE, RUSSIA
}

\author{
Tatyana MODZALEVSKAYA ${ }^{\mathrm{a}}$ and Madis RUBEL $^{\mathrm{b}}$
}

a All-Russian Geological Research Institute (VSEGEI), Srednij Ave 74, 199106 St. Petersburg, Russia; modz@IB2567.spb.edu

b Institute of Geology, University of Tartu, Vanemuise 46, 51014 Tartu, Estonia; rubel@ut.ee

Received 18 October 1999, in revised form 23 December 1999

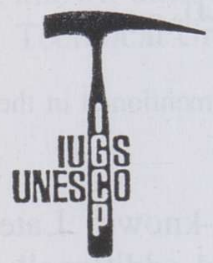

IGCP Project 406

Circum-Arctic Lower-

Middle Palaeozoic

Vertebrate Palaeontology

and Biostratigraphy

\begin{abstract}
Revision of the pentamerid brachiopod Pentamerus samojedicus Keyserling, 1846 allows it to be assigned to the genus Borealis Boucot, Johnson \& Rubel, 1971, and shows its much wider distribution than originally reported, from the Aeronian to Telychian in the Timan Ridge, Severnaya Zemlya, and the Baltic region. The gradational evolution from Borealis borealis to P. oblongus, as supposed and documented by Mørk using Norwegian material (Palaeontology, 1981, 24, 537-553), has a parallel branch through B. samojedicus, which occupies a transitional position in the Baltic sections.
\end{abstract}

Key words: brachiopods, pentamerids, Llandovery, Timan Ridge, Baltic.

\section{INTRODUCTION}

Keyserling (1846) discovered Silurian deposits from the Timan Ridge on the shore of the Arctic Ocean, and in the palaeontological part of his travel notes he described a new brachiopod species as Pentamerus samojedicus. Numerous shells of this pentamerid brachiopod were found by him in outcrops along the Vas'kina (Washkina) River on the Barmin Cape, where they formed a coquina. Somewhat later and not far from this locality, on the banks of the Chernaya River, Stuckenberg (1874) described the same beds with abundant $P$. samojedicus (see Fig. 1). 


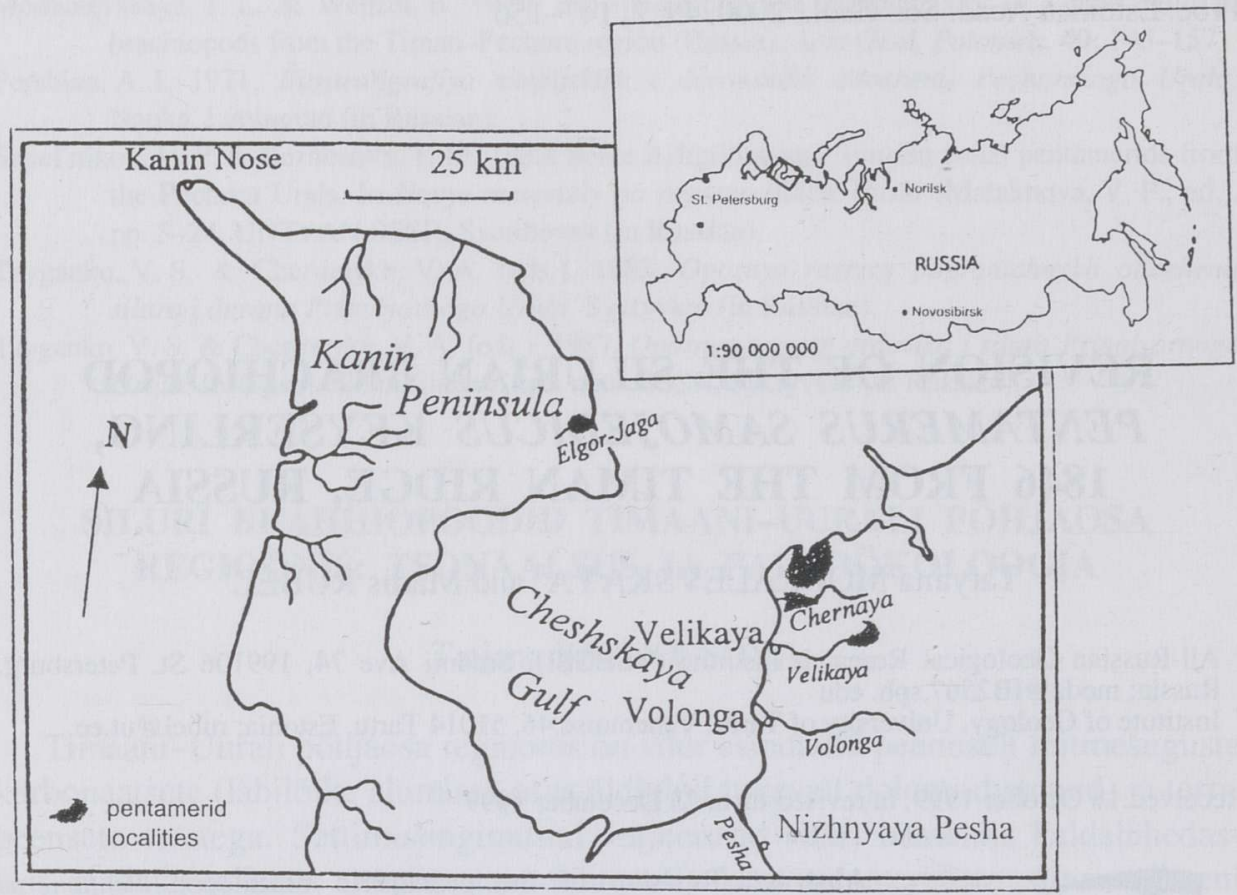

Fig. 1. Map showing the location of the Timan Ridge and pentamerid localities mentioned in the text.

Lebedeff (1892) compared P. samojedicus with the then-known Late Llandovery British and Baltic species of this genus and described additionally a new species $P$. schmidti from the Silurian of Tunguska, Siberia. According to Lebedeff, the otherwise similar species $P$. oblongus and P. esthonus could be easily distinguished from each other by the relative heights of their ventral septum. The high ventral septum alone makes $P$. samojedicus closer to $P$. esthonus and $P$. schmidti than to P. oblongus; the understanding of these taxa, especially $P$. oblongus and $P$. esthonus, was clearly different to Lebedeff from previous authors. Lebedeff noted also the wide base of the spondylium in $P$. samojedicus, which is narrow at least in P. oblongus and P. esthonus. After these early contributions, $P$. samojedicus was forgotten or overlooked for a long time.

In their systematic list of the Pentameridae, Boucot \& Johnson (1979) assigned P. samojedicus to the genus Borealis Boucot, Johnson \& Rubel, 1971 in the subfamily Virgianinae, although only questionably. But Sapelnikov \& Beznosova (1980) examined (probably exteriors) the Timan species mostly from the Chernaya River and put $P$. samojedicus into synonymy with $P$. oblongus, i.e. to a species of the subfamily Pentamerinae (see also Sapelnikov 1985, p. 59). It is notable that in spite of the quite clear differences in the interiors of these subfamilies, the genera Borealis and Pentamerus were considered by Mørk 
(1981) as members of the same phyletic lineage which was well documented at least in the Norwegian Llandovery.

The transition described by Mørk (1981) from B. borealis to P. oblongus through an intermediate $B$. borealis osloensis is comparable with the evolutionary lineages of other Silurian brachiopods like Stricklandia and Eocoelia, both used widely in chronostratigraphic correlations (Ziegler 1966; Baarli 1986; Baarli \& Johnson 1988). Determination of the position of P. samojedicus in relation to Mørk's lineage may be useful for some chronostratigraphic implications and is also discussed below.

The collection studied by us includes 116 often deformed shells of different sizes. They were collected by V. P. Barkhatova in 1936, V. A. Filippov in 1937, L. S. Kossovoj in 1957, and V. A. Raznitsyn in 1966, from the Chernaya and Vas'kina River sections. All are in collection 13044 of Central ScientificResearch Geological Exploration Museum (CNIGRM), St. Petersburg, Russia. Additionally, the collection made by A. Keyserling (1846) has been studied in the Museum of the Institute of Mines, St. Petersburg.

Identification of $P$. samojedicus from Latvia was based on the specimens described as P. oblongus by Rybnikova (Gailite et al. 1967), housed in the Museum of Natural History of Latvia (MNHL), Riga. The Estonian specimens known until now as $P$. cf. oblongus are housed in the Institute of Geology of the Technical University of Tallinn (IG), Estonia.

\section{SYSTEMATIC DESCRIPTION}

\section{Borealis samojedicus (Keyserling, 1846)}

Plate I, figures 1-9; Plate II, figures 1-7

1846 Pentamerus samojedicus n. sp.; Keyserling, p. 235, pl. 9, figs. 2, 2a-h.

1892 Pentamerus samojedicus Keyserling; Lebedeff, p. 20.

1967 Pentamerus oblongus Sowerby; Gailite et al., p. 181, pl. 17, fig. 1.

1980 Pentamerus oblongus Sowerby; Sapelnikov \& Beznosova, p. 10 (pars), pl. 5, figs. 1-5.

1985 Pentamerus oblongus Sowerby; Sapelnikov, pl. 19, figs. 3, 4.

Lectotype. Conjoined valves 136a, b/46, selected here from the Keyserling (1846) collection in the Museum of the Institute of Mines, St. Petersburg. Chernaya Reka Formation, Llandovery Series, Vas'kina River section, Timan Ridge, Russia.

Description. Shell large, ventribiconvex; outline elongate, subtriangular, with relatively sharpened ventral umbo and weak medial extension at the anterior margin. Lateral margins expand to maximum width in the anterior one-quarter. Median fold developed in the anterior part of both valves. Anterior commissure rectimarginate. 
Exterior smooth, with inconspicuous radial furrows in the anterior part of the shell and sometimes one medial furrow in both valves. Concentric growth lines frequently developed, not sharp.

Spondylium long, curved, with a flat floor and evenly widening lateral sides (Fig. 2). Ventral septum extends for up to one-third of the shell length. Secondary deposits developed posteriorly.

Outer brachial plates short, up to one-quarter of the valve length, subparallel, distinct (Fig. 3). Inner plates as long as outer plates, ventrally divergent. Brachial processes rod- to plate-like, distinct, longer than brachial plates, located between the latter plates.

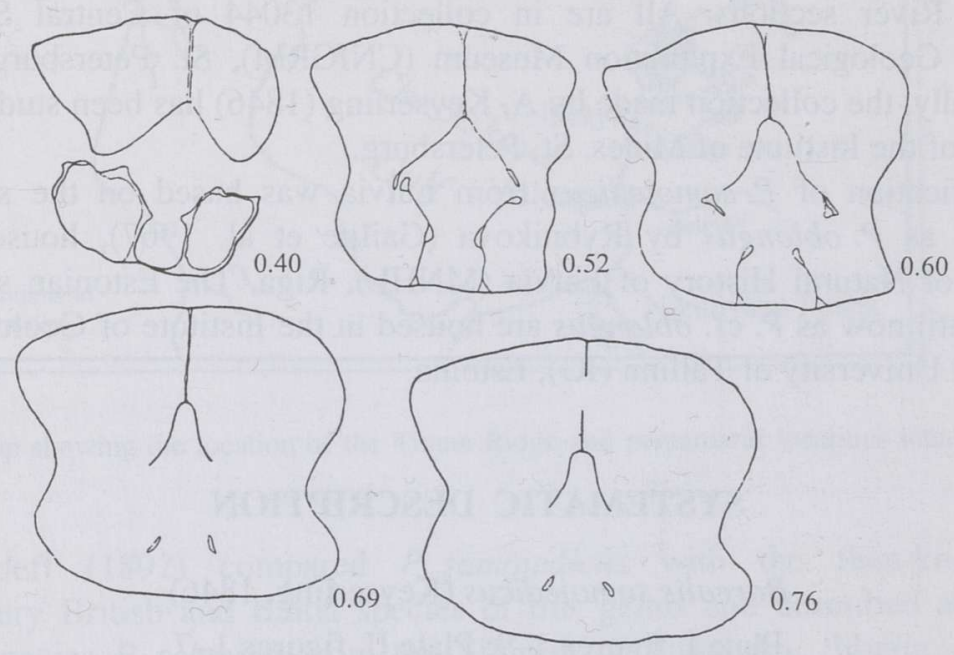

Fig. 2. Serial sections from the umbonal part of shell CNIGRM 5/13044 of Borealis samojedicus from the Chernaya Reka Formation, Aeronian of the Timan Ridge. Distances between sections are in millimetres, $\times 1.5$.

\section{Explanation of Plate I}

Pentamerus samojedicus (Keyserling)

Figs. 1-4. Ventral, dorsal, lateral, and posterior views of partly preserved shell CNIGRM 1/13044. Timan Ridge, Chernaya River, Middle Llandovery, Chernaya Reka Formation, coll. by V. P. Barkhatova, $\times 1$.

Figs. 5-8. Ventral, dorsal, anterior, and posterior views of young shell CNIGRM 4/13044. Timan Ridge, Vas'kina River, Chernaya Reka Formation, coll. by L. S. Kossovoj, $\times 2$.

Fig. 9. Ventral view of partly preserved shell CNIGRM 2/13044. Timan Ridge, Chernaya River, Middle Llandovery, Chernaya Reka Formation, coll. by V. P. Barkhatova, $\times 1$. 
PLATE I
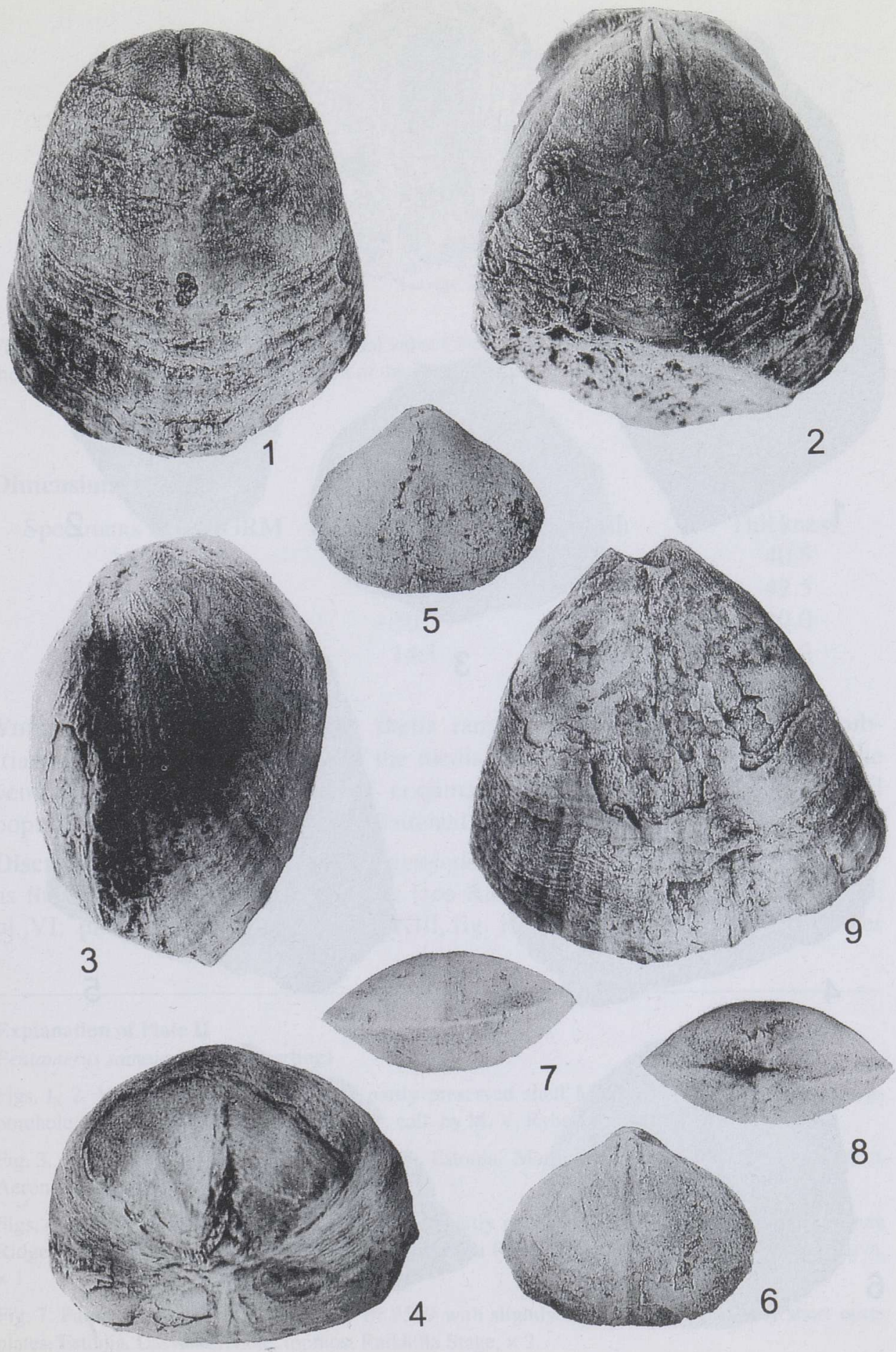

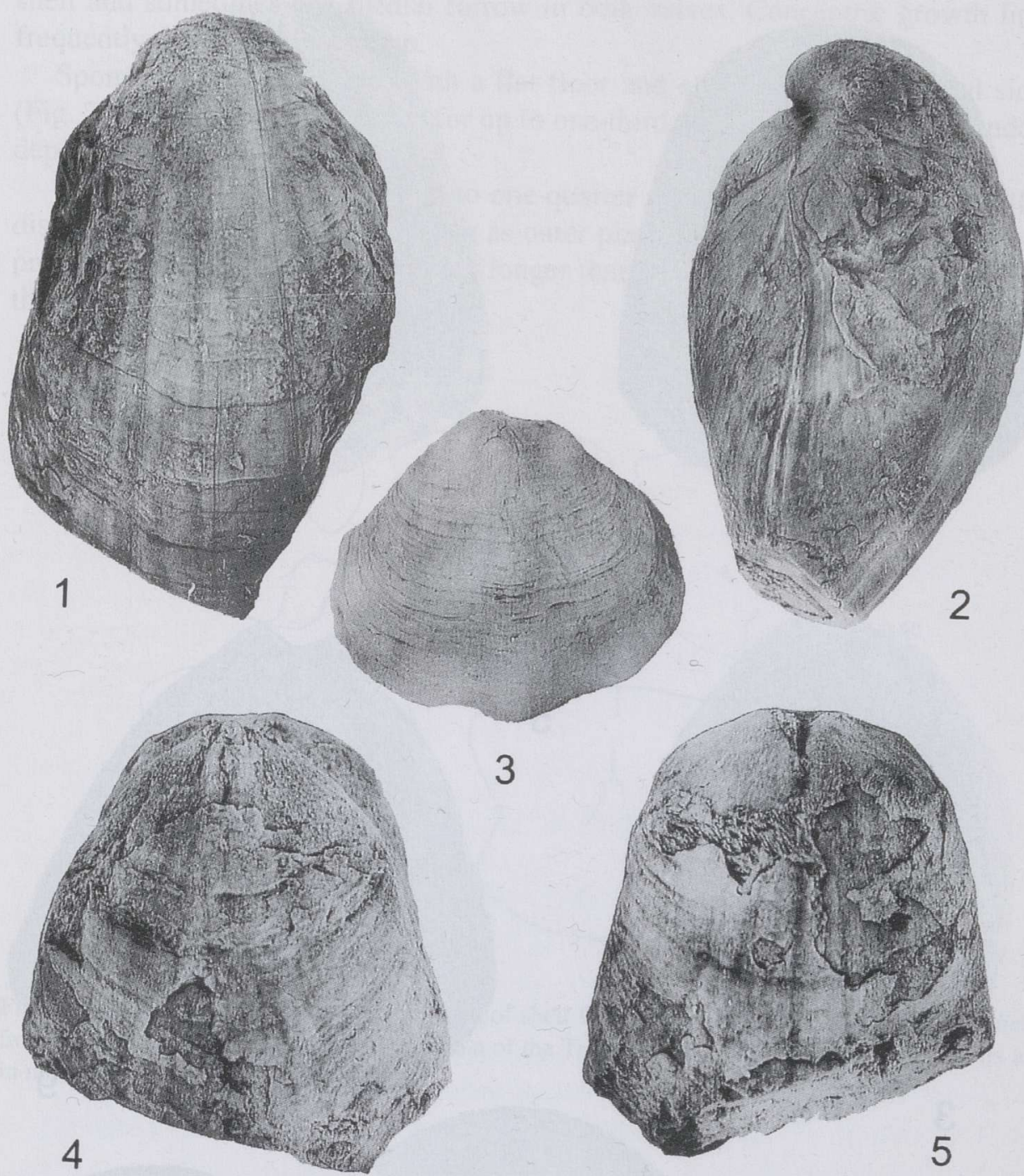

3
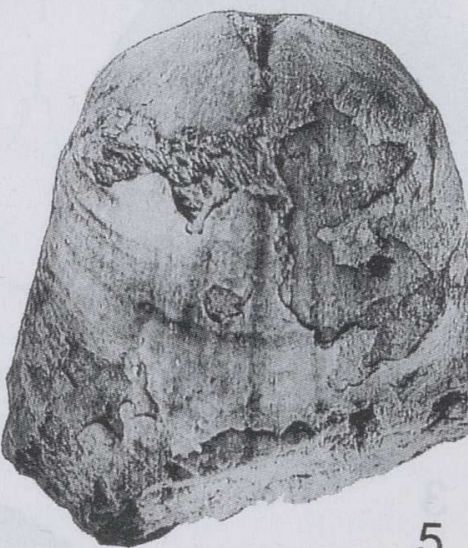


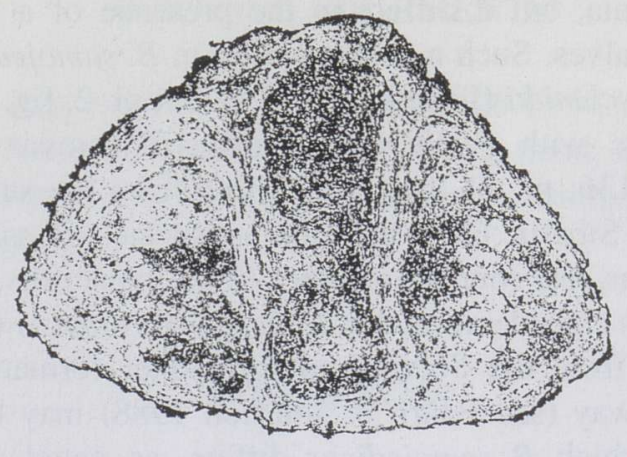

Fig. 3. Peel from the umbonal part of dorsal valve CNIGRM 5/13044 of Borealis samojedicus from the Chernaya Reka Formation, Aeronian of the Timan Ridge.

\section{Dimensions in $\mathrm{mm}$.}

$\begin{array}{cccc}\text { Specimens in CNIGRM } & \text { Length } & \text { Width } & \text { Thickness } \\ 1 / 13044 & \sim 59.0 & 53.6 & 40.5 \\ 2 / 13044 & \sim 56.5 & 9.3 & 42.5 \\ 3 / 13044 & \sim 50.5 & 46.5 & 40.0 \\ 4 / 13044 & 14.1 & 17.6 & 8.3\end{array}$

Variability. The outline of the shells ranges from rounded to clearly subtriangular forms. Development of the median fold is variable, especially on the ventral valve. The specimens of coquinas, probably derived from crowded populations, exhibit more laterally flattened shells and narrow spondyliums.

Discussion. It is quite clear that $B$. samojedicus has the same interior morphology as the type of the genus, B. borealis (see Rubel 1970, p. 17; pl. V, figs. 8-14; pl. VI; pl. VII; pl. X, fig. 19; pl. XXIII, fig. 16) from the Juuru Stage, Lower

\section{Explanation of Plate II}

\section{Pentamerus samojedicus (Keyserling)}

Figs. 1, 2. Ventral and lateral views of partly preserved shell MNHL Br 30/53. Latvia, Druvas borehole, depth $287.4 \mathrm{~m}$, Upper Llandovery, coll. by M. V. Rybnikova, $\times 0.7$.

Fig. 3. Exterior of dorsal valve IG $\mathrm{Br}$ 1867. Estonia, Martna borehole, depth $23.42-23.46 \mathrm{~m}$, Aeronian, Raikküla Stage, $\times 0.7$.

Figs. 4-6. Dorsal, ventral, and posterior views of partly preserved shell CNIGRM 3/13044. Timan Ridge, Chernaya River, Middle Llandovery, Chernaya Reka Formation, coll. by V. P. Barkhatova, $\times 1$.

Fig. 7. Partly preserved dorsal valve IG $\mathrm{Br} 3599$ with slightly divergent and relatively short outer plates, Estonia, Laeva borehole, topmost Raikküla Stage, $\times 2$. 
Llandovery of Estonia, but it differs in the presence of a fold, which can be developed in both valves. Such a trilobed shell in B. samojedicus makes it more comparable with B. schmidti (Lebedeff 1892, p. 23; pl. 2, fig. 9), as well as being probably conspecific with $P$. oblongus sensu Nikiforova (see Nikiforova \& Andreeva 1961, p. 136; pl. 24, figs. 1-3), both from the same localities of the Moyerocan Stage of Siberia. From the Siberian species, B. samojedicus differs in its more subtriangular, less rounded outline. At the same time, the high variability of B. schmidti allows consideration that B. borealis osloensis (Mørk 1981, p. 544; pl. 84, figs. 9-11) from the Solvik and Rytteråker formations, Aeronian and Rhuddanian of Norway (see Baarli \& Johnson 1988) may be conspecific with B. schmidti, from which B. samojedicus differs, as noted above, in its wider subtriangular shell and medially flattened trilobation.

Distribution. Chernaya Reka Formation, Rhuddanian-early Aeronian of the Timan Ridge; Snezhninka Formation, Aeronian of Severnaya Zemlya; Aeronian to Telychian (?) of Estonia and Latvia.

\section{PHYLOGENETIC AND CLASSIFICATORY IMPLICATIONS}

The quite stable interiors (relatively short and weakly divergent to subparallel brachial plates, broad spondylium with flattened floor) relate the species compared above with B. samojedicus, as well as some other early smooth virgianiids from China with a highly ventribiconvex shell (see Rong \& Yang 1977). These features define the genus Borealis or, in other words, the absence or presence of folds (trilobation) is not diagnostic for this genus as originally supposed (Boucot et al. 1971). Phylogenetically, a Borealis-type spondylium and cardinalia preceded a narrow spondylium, and long plate-like brachial plates with a process between them as they were replaced in Pentamerus and related genera in the Late Llandovery.

Of the Rhuddanian (oldest) species of the genus Borealis, the Baltic B. borealis has no folds on its shell. At the same time, B. cristiformis (Modzalevskaya 1985) from the Lower Persej and Vodopad formations in the lowermost Rhuddanian of Novaya Zemlya and Severnaya Zemlya, respectively, has conspicuous folds on both valves. The latter species could be considered therefore as a possible ancestor to the clearly trilobed B. schmidti from the Llandovery of Siberia, as well as conspecific with B. borealis osloensis from Norway (see above). The Norwegian material of the latter subspecies has been documented in relation to its transition to P. oblongus (Mørk 1981). But, as now appears, B. borealis borealis is the closest species (ancestor) to B. samojedicus, which in turn has a clear transitional succession (see Pl. 2, fig. 7) to P. oblongus in the Baltic Aeronian. There is thus a possible polyphyletic origin (reticulate evolution) in the Late Llandoverian species P. oblongus. 


\section{ACKNOWLEDGEMENTS}

This study was supported by IGCP Project 406 (T.M.) and grant No. 3274 from the Estonian Science Foundation (M.R.). We thank the reviewer Michael Bassett and an anonymous referee for critical comments and substantial improvement of English.

\section{REFERENCES}

Baarli, B. G. 1986. A biometric re-evaluation of the Silurian brachiopod lineage Stricklandia lens/S. laevis. Palaeontology, 29, 187-205.

Baarli, B. G. \& Johnson, M. E. 1988. Biostratigraphy of key brachiopod lineages from the Llandovery Series (Lower Silurian) of the Oslo Region. Norsk Geol. Tidsskr., 68, 259274.

Boucot, A. J. \& Johnson, J. G. 1979. Pentamerinae (Silurian Brachiopoda). Palaeontographica, A $163,12-129$.

Boucot, A. J., Johnson, J. G. \& Rubel, M. 1971. Description of brachiopod genera of subfamily Virgianinae Boucot et Amsden, 1963. ENSV TA Toim. Keem. Geol., 20, 271-280.

Keyserling, A. 1846. Geognostische Beobachtungen. In Wissenschaftliche Beobachtungen auf einer Reise in das Petschora-Land im Jahre 1843, pp. 151-406. St. Petersburg.

Lebedeff, N. 1892. Obersilurische Fauna des Timan. Mem. Com. Geol., 12, 36-48.

Modzalevskaya, T. L. 1985. Early Silurian brachiopods from the Southern Island of Novaya Zemlya. In Stratigrafiya i fauna paleozoya Novoj Zemli (Bondarev, V. I., ed.), pp. 57-77. Sevmorgeo, Leningrad (in Russian).

Mørk, A. 1981. A reappraisal of the Lower Silurian brachiopods Borealis and Pentamerus. Palaeontology, 24, 537-553.

Nikiforova, O. I. \& Andreeva, O. N. 1961. Ordovician and Silurian stratigraphy of the Siberian Platform and its palaeontology (Brachiopoda). Tr. VSEGEI, novaya seriya, $\mathbf{5 6}$ (in Russian).

Rong Jia-yu and Yang Xuechang. 1977. On Pleurodium and its relative genera. Acta Palaeontol. Sinica, 16, 73-80.

Rubel, M. 1970. Brachiopods Pentamerida and Spiriferida of the Silurian of Estonia. Valgus, Tallinn (in Russian).

Gailite, L. K., Rybnikova, M. V. \& Ulst, R. Zh. 1967. Stratigrafiya, fauna i usloviya obrazovaniya silurijskikh porod srednej Pribaltiki. Zinatne, Riga (in Russian).

Sapelnikov, V. P. 1985. System and Stratigraphical Significance of the Brachiopods of the Suborder Pentameridina. Nauka, Moscow (in Russian).

Sapelnikov, V. P. \& Beznosova, T. M. 1980. Some key forms of Ashgillian and Silurian pentamerids of the Pechora Urals. In Novye materialy po pentameridam Urala (Malakhova, N. P., ed.). Preprint. Sverdlovsk (in Russian).

Stuckenberg, A. A. 1874. Report of the geological excursion to the Pechora Region and Timanian Tundra. In Materialy po geologii Rossii, Vol. 6, pp. 59-64 (in Russian).

Ziegler, A. M. 1966. The Silurian brachiopod Eocoelia hemisphaerica (J. de C. Sowerby) and related species. Palaeontology, 9, 523-543. 


\section{SILURI PENTAMERIIDNE BRAHHIOPOOD PENTAMERUS SAMOJEDICUS KEYSERLING, 1846 TIMAANI AHELIKUST (VENEMAA): REVISJON}

Tatjana MODZALEVSKAJA ja Madis RUBEL

Brahhiopoodi Pentamerus samojedicus Keyserling, 1846 olemasoleva kollektsiooni lisauurimine näitas tema kuulumist perekonda Borealis Boucot, Johnson \& Rubel, 1971. Revideeritud liik identifitseeriti peale Timaani aheliku Aeroni ja varajase Telychi veel Severnaja Zemlja ning ka Eesti ja Läti Aeronis või isegi Telychis. Eesti ja Läti Borealis samojedicus'e leiud ei kinnita Mørki oletatud (Norra materjalil dokumenteeritud; Mørk 1981) arengurida B. borealis'e ja $P$. oblongus'e vahel, vaid näitavad hoopis $P$. oblongus'e võimalikku polüfüleetilist päritolu.

\section{РЕВИЗИЯ СИЛУРИЙСКИХ БРАХИОПОД ВИДА РЕNTAMЕRUS SAMOJEDICUS KEYSERLING, 1846 С ТИМAНA, РОССИЯ}

Татьяна МОДЗАЛЕВСКАЯ и Мадис РУБЕЛЬ

Проведена ревизия брахиопод Pentamerus samojedicus Keyserling, 1846 , на основе которой они отнесены к роду Borealis Boucot, Johnson и Rubel, 1971. Установлен возрастной диапазон этого рода на Тимане, Северной Земле и в Балтийском регионе от эрона до телича, т.е. он оказался гораздо шире, чем предполагалось ранее. Предложенный на норвежском материале Мерком эволюционный ряд от Borealis borealis к Pentamerus oblongus имеет параллельную ветвь через Borealis samojedicus, который занимает промежуточное положение в Балтийских разрезах. 